\title{
Efek Kurkumin terhadap Pertumbuhan dan Perkembangan Fetus Rattus norvegicus $\mathbf{L}$.
}

\author{
The Effects of Curcumin on the Growth and Development of Rattus norvegicus L. \\ Foetuses
}

\section{Istriyati}

Lab. Histologi-Embriologi Hewan, Fakultas Biologi Universitas Gadjah Mada Jl. Teknika Selatan Sekip Utara Yogyakarta

E-mail: istriyati@yahoo.com

\begin{abstract}
Curcumin which is isolated from Curcuma longa $\mathrm{L}$. rhizome, has been used as a food additive, medicinal agent, cosmetic and fabric dye, whithout known its side effects. This research is to study the effects of curcumin on the structure of forelimb finger. Twenty virgin female rats, 2 month old, $150 \mathrm{~g}$ body weight were mated with fertile male rats. The present of vaginal plug or spermatozoa in the vagina were determined as the first day of pregnancy. Pregnant animals were devided into 4 groups of 5. Treatment were started from $10^{\text {th }}$ to $17^{\text {th }}$ day of pregnancy. The first 2 groups for control and vehicle only. Curcumin was dissolved in aquous 5\% Tween 80. The second 2 groups were given curcumin at the dosage of 100 and $150 \mathrm{mg} \mathrm{kg}^{-1} \mathrm{bw}$. Rats were sacrificed at $18^{\text {th }}$ day of pregnancy. Foetuses were dissected out, fixed in $10 \%$ formalin. Morphology of the foetuses were observed, forelimb were processed by paraffin method, and plantar paraffin section were made and used for histological observations and cell development of fingers. The results showed that curcumin at the dosage of $100 \mathrm{mg} \mathrm{kg}^{-1}$ body weight caused some foetuses dead, resorption of the embryo, hemorrhagi, unilateral phocomelia. Microscopical observations showed the treatment caused induced of nail formation, inhibition of indensity interdigity, and the increased of new blood vessel formation. It was concluded that the curcumin has no effect on the growth of foetuses. However it was affected the development of forelimb finger which is non dosage dependent.
\end{abstract}

Key words: curcumin, foetuses, forelimb, structure, Rattus noevegicus L.

Diterima: 23 April 2008, disetujui: 10 Desember 2008

\section{Pendahuluan}

Ekstrak rimpang kunyit (Curcuma longa L.) dan temu lawak (Curcuma xanthorrhizi Robx) merupakan sumber alami kurkumin. Senyawa ini banyak digunakan sebagai food additive, medical agent, kosmetik, dan fabric dye (Majeed et al., 1995). Joe et al., (2004) menyebutkan aktivitas kurkumin antara lain sebagai agensia apoptosis dan anti mitosis pada proliferasi sel. Menurut Jiang et al., (1996) kurkumin mempunyai aktivitas menghambat kanker kulit pada mencit, efek antiproliferasi, dan efek apoptosis sel-sel otot polos pembuluh darah disebutkan oleh Chen dan Huang (1998).

Pan et al., (1999) menyebutkan bahwa kurkumin mempunyai aktivitas antikarsinogenik dan antioksidan pada mencit. Kurkumin sebagai salah satu komponen diet pada penderita kanker prostat, mempunyai aktivitas menginduksi apoptosis pada penderita kanker prostat yang androgen dependent dan androgen independent (Dorai et al., 2001).

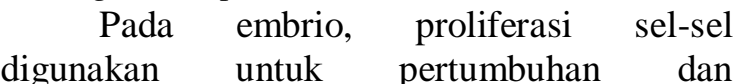
perkembangan. Di masyarakat kunyit sering digunakan pada wanita hamil untuk menjaga kesehatannya. Meskipun banyak kegunaannya 
sebagai jamu, perlu diteliti efeknya terhadap janin atau fetus yang dikandungnya. Diketahui bahwa kandungan kimia kunyit adalah kurkuminoid dan minyak atsiri. Menurut Chattopadhyay et al., (2004) kurkuminoid ini terdiri dari banyak senyawa yang antara lain kurkumin, demetoksikurkumin, dan bisdemetoksikurkumin, serta diungkapkan mempunyai aktivitas antifertilitas pada tikus yang berupa hambatan implantasi bila diberikan secara oral. Aktivitas biologi kurkumin sangat luas, tetapi baru sedikit penelitian dalam bidang biologi perkembangan.

Pada penelitian Haryono (2005), mencit SW umur kebuntingan 11 hari yang diberi MAA $10 \mathrm{mM} / \mathrm{kg}$ bb menyebabkan kecacatan pada fetus yang berupa tidak terbentuknya jari ke I, II, III, dan V. Sayatan plantar tunas anggota tubuh depan mencit SW pada 11 hari umur kebuntingan tersusun antara lain lapisan ektodermal, mesodermal, sinus marginalis dan arteri aksial primer. Secara histologis lapisan mesodermal tersusun dari sel-sel mesenkhim, sel-sel ini akan berdiferensiasi menjadi kondroblas selanjutnya menjadi sel-sel tulang. Pada perkembangannya, sel-sel ini dapat mengalami kematian sel yang berupa nekrosis dan atau apoptosis. Periode kritis perkembangan hewan adalah fase organogenesis, pada hari ke-8 sampai 12 umur kebuntingan, yang sangat rentan terhadap senyawa kimia asing. Efek samping senyawa tersebut dapat berupa embrio toksik, yang langsung menyebabkan hasil konsepsi mati atau berakhir dengan abortus atau berupa kecacatan morfologis (teratogenik).

Tujuan penelitian ini untuk mempelajari efek kurkumin terhadap pertumbuhan dan perkembangan serta struktur jari tungkai depan fetus Rattus norvegicus L. yang mengalami kelainan karena kurkumin.

\section{Metode Penelitian}

Penelitian ini dilakukan dengan pola Rancangan Acak Lengkap (RAL) dengan empat perlakuan dan lima kali ulangan per perlakuan dilanjutkan dengan uji LSD 5\%. Dua puluh ekor tikus Rattus norvegicus strain Wistar, umur kebuntingan (u.k.) 10 hari didapat dari LP3HP-LPPT-UGM. Kurkumin (ROTH Jerman) kemurnian 99\% didapat dari Pusat Studi Obat Alami (PSOA-UGM). Hewan uji dibagi dalam empat kelompok secara acak, masing-masing lima ekor/kelompok. 1) Kelompok kontrol $\left(\mathrm{K}^{-}\right)$, adalah kelompok hewan yang dicekok dengan aquabides sebanyak 0,5 ml. 2) Kelompok plasebo (pelarut) $\left(\mathrm{K}^{+}\right)$, adalah kelompok yang dicekok dengan 5\% Tween 80 dalam akuabides sebanyak 0,5 ml. 3) Kelompok perlakuan (P1) yang dicekok dengan kurkumin $100 \mathrm{mg} / \mathrm{kg}$ bb dalam 5\% Tween 80 (diberikan dua kali sehari, pagi $50 \mathrm{mg}$ dan sore $50 \mathrm{mg} / \mathrm{kg}$ bb). 4) Kelompok perlakuan (P2) yang dicekok dengan kurkumin $150 \mathrm{mg} / \mathrm{kg}$ bb dalam 5\% Tween 80 (diberikan dua kali sehari, pagi $75 \mathrm{mg}$ dan sore $75 \mathrm{mg} / \mathrm{kg} \mathrm{bb}$ ).

Perlakuan diberikan pada hari ke-10 umur kebuntingan, selama 8 hari. Hewan dikorbankan pada hari ke-18 umur kebuntingan. Uterus beserta fetus dikeluarkan, dicuci dalam aquades, dihitung jumlah total fetus, masing-masing fetus ditimbang berat badannya dan diukur panjangnya, kemudian dimasukkan dalam larutan formalin $10 \%$, diamati bentuk tungkai depan, terbentuktidaknya jari tungkai depan, selanjutnya tungkai depan dipotong untuk sayatan planar dengan metode parafin, sayatan setebal $6 \mu \mathrm{m}$, diwarnai dengan hematoksilin dan eosin (H.E.). Dengan mikroskop cahaya diamati struktur jari tungkai depan fetus, lapisan ektoderm, mesoderm, dan jaringan antar jari.

Dalam penelitian ini diamati juga pertumbuhan dan perkembangan fetus. Parameter utamanya adalah pembentukan jari yaitu apakah terjadi pembentukan atau tidak terjadi pembentukan jari.

Data kuantitatif dianalisis secara statistik (ANOVA, LSD 5\%). Hasil pengamatan sayatan plantar jari tungkai depan disajikan dalam tabel dan gambar.

\section{Hasil dan Pembahasan}

\section{Kenaikan berat badan (g) tikus putih bunting selama perlakuan}

Perhitungan berat badan tikus putih bunting kelompok kontrol dan perlakuan 
selama penelitian tidak menunjukkan penurunan. Dengan menimbang jumlah sisa pakan harian menunjukkan bahwa kurkumin yang diberikan pada induk bunting, nafsu makan tidak hilang. Berdasarkan hal tersebut dinyatakan bahwa kurkumin tidak toksik dalam penelitian ini. Pernyataan ini didukung oleh hasil penelitian Huang et al., (1995) yang menyatakan bahwa pemberian $2 \%$ kurkumin dalam pakan mencit selama 25 minggu tidak menyebabkan perubahan berat badan, sehingga dipercaya bahwa dosis $2 \%$ tersebut tidak toksik pada mencit. Dosis efektif (ED) kurkumin pada tikus adalah 100,2 $\mathrm{mg} / \mathrm{kg}$ bb (Majeed et al., 1995). Hasil penelitian Ishida et al., (2004) menyimpulkan bahwa kurkumin mengurangi efek yang merugikan seperti penurunan berat mencit yang disebabkan oleh pemberian tetrachlorodibensol-p-dioxin (TCDD). Dengan demikian berat badan tikus bunting dalam penelitian ini menunjukkan kenaikan yang tidak bermakna (Tabel 1).

Tabel 1. Kenaikan berat badan (g) tikus bunting diberi kurkumin.

\begin{tabular}{|c|c|c|c|c|c|}
\hline & \multirow[t]{2}{*}{$\mathbf{n}$} & \multicolumn{3}{|c|}{ Berat (g) } & \multirow[t]{2}{*}{ Rata-rata $\Delta$} \\
\hline & & Awal & Akhir & $\Delta$ & \\
\hline \multirow[t]{5}{*}{$\overline{\mathrm{K}^{-}}$} & $\overline{11}$ & $\overline{177,5}$ & 284,3 & $\overline{106,8}$ & $66,9 \pm 23,1^{a}$ \\
\hline & 2 & 163 & 222 & 59 & \\
\hline & 3 & 179 & 228,6 & 49,6 & \\
\hline & 4 & 180,7 & 246 & 65,3 & \\
\hline & 5 & 195,6 & 249,3 & 53,7 & \\
\hline \multirow[t]{5}{*}{$\mathrm{K}^{+}$} & 1 & 136,6 & 227,6 & 91 & $77,7 \pm 13,1^{\mathrm{a}}$ \\
\hline & 2 & 176,3 & 246,1 & 69,8 & \\
\hline & 3 & 154 & 245,3 & 91,3 & \\
\hline & 4 & 177,5 & 252,2 & 74,7 & \\
\hline & 5 & 197 & 258,7 & 61,7 & \\
\hline \multirow[t]{5}{*}{ P1 } & 1 & 170,9 & 215,9 & 45 & $64,5 \pm 32,3^{\mathrm{a}}$ \\
\hline & 2 & 204,1 & 303,1 & 99 & \\
\hline & 3 & 193 & 281,4 & 88,4 & \\
\hline & 4 & 198,2 & 268,7 & 70,5 & \\
\hline & 5 & 177,7 & 197,4 & 19,7 & \\
\hline \multirow[t]{5}{*}{$\mathrm{P} 2$} & 1 & 161,8 & 230,1 & 68,3 & $77,2 \pm 10,7^{\mathrm{a}}$ \\
\hline & 2 & 171,1 & 260,3 & 89,2 & \\
\hline & 3 & 181,6 & 269,7 & 88,1 & \\
\hline & 4 & 188,8 & 256,2 & 67,4 & \\
\hline & 5 & 185,4 & 258,2 & 72,8 & \\
\hline
\end{tabular}

Keterangan: $\mathrm{n}=$ jumlah tikus bunting.

Tabel 2. Efek kurkumin terhadap fetus dari induk yang diberi kurkumin pada hari ke-10 umur kebuntingan.

\begin{tabular}{|c|c|c|c|c|}
\hline $\begin{array}{l}\text { Perlakuan } \\
\text { Parameter }\end{array}$ & $\mathbf{K}^{-}$ & $\mathbf{K}^{+}$ & $\mathbf{P 1}$ & $\mathbf{P 2}$ \\
\hline Rata2 jumlah & $\begin{array}{c}8,8 \pm 2,4^{\mathrm{a}} \\
(\mathrm{n}=44)\end{array}$ & $\begin{array}{l}11 \pm 1^{\mathrm{a}} \\
(\mathrm{n}=55)\end{array}$ & $\begin{array}{c}11,7 \pm 1,5^{\mathrm{a}} \\
(\mathrm{n}=35)\end{array}$ & $\begin{array}{l}9 \pm 2,3^{\mathrm{a}} \\
(\mathrm{n}=45)\end{array}$ \\
\hline $\mathbf{x}$ berat badan $(\mathrm{g})$ & $1,2 \pm 0,3^{\mathrm{a}}$ & $1,3 \pm 0,3^{\mathrm{a}}$ & $1,2 \pm 0,7^{\mathrm{a}}$ & $1,3 \pm 0,4^{\mathrm{a}}$ \\
\hline panjang $(\mathrm{cm})$ & $5,07 \pm 0,1^{\mathrm{a}}$ & $5,3 \pm 0,4^{\mathrm{a}}$ & $5,1 \pm 0,3^{\mathrm{a}}$ & $5,1 \pm 0,1^{\mathrm{a}}$ \\
\hline$\%$ hidup & $82 \pm 0,3^{\mathrm{a}}$ & $85 \pm 0,1^{\mathrm{a}}$ & $77 \pm 1,2^{b}$ & $78 \pm 1,6^{\mathrm{b}}$ \\
\hline$\%$ mati & $0^{\mathrm{a}}$ & $0^{\mathrm{a}}$ & $2,9^{\mathrm{b}}$ & $0^{\mathrm{a}}$ \\
\hline$\%$ hemoragi & $0^{\mathrm{a}}$ & $0^{\mathrm{a}}$ & $0^{\mathrm{a}}$ & $2,2^{\mathrm{b}}$ \\
\hline$\%$ resorpsi & $9,1^{\mathrm{a}}$ & $7,3^{\mathrm{b}}$ & $8,6^{\mathrm{a}}$ & $2,2^{\mathrm{c}}$ \\
\hline$\%$ cacat anggota gerak depan & $0^{\mathrm{a}}$ & $0^{\mathrm{a}}$ & $2,9^{\mathrm{b}}$ & $0^{\mathrm{a}}$ \\
\hline
\end{tabular}

Keterangan : $\mathrm{K}^{-}$: kelompok tikus bunting yang dicekok aquabides; $\mathrm{K}^{+}$: kelompok tikus bunting yang dicekok $5 \%$ T-80 dalam aquabides; P1: kelompok tikus bunting yang dicekok kurkumin $100 \mathrm{mg} / \mathrm{kg}$ bb dalam 5\% Tween 80; P2: kelompok tikus bunting yang dicekok kurkumin $150 \mathrm{mg} / \mathrm{kg}$ bb dalam 5\% Tween 80; $\mathrm{n}$ $=$ jumlah fetus. 


\section{Hasil pengamatan fetus kontrol dan perlakuan}

Endometrium tersusun dari lapisan epithelium dan lamina propria yang berisi kelenjar tubuler bercabang. Setelah implantasi, endometrium mengalami perubahan yang sangat drastis dan disebut desidua. Sel-sel stroma membesar bentuk menjadi polygonal dan disebut sel-sel desidua. Dalam keadaan ini desidua dapat dibagi menjadi desidua basalis, terletak antara embrio dan miometrium; desidua kapsularis terletak antara embrio dan lumen uterus, dan desidua parietalis adalah sisa jaringan desidua lainnya.

Data Tabel 2 menunjukkan bahwa ratarata jumlah, berat badan dan panjang fetus antara kelompok kontrol dan perlakuan menunjukkan perbedaan yang tidak bermakna.

Kelompok P1 dan P2 fetus yang hidup menunjukkan penurunan yang bermakna. Kelompok P1 dijumpai adanya fetus yang mati sedangkan fetus yang mengalami hemoragi hanya terdapat pada kelompok P2. Kelompok P2 fetus yang resorpsi menurun secara signifikan, sedangkan fetus yang mengalami cacat anggota gerak depan pada kelompok P1 yang berupa phocomelia unilateral.

Menurut Hastati (2006) kurkumin menghambat sintesis prostaglandin dengan cara inaktivasi cyclooxygenase. Peran enzim dalam sistem reproduksi adalah mengkonversi asam arakhidonat menjadi prostaglandin. Hormon ini berperan dalam ovulasi, fertilisasi, implantasi, dan desidualisasi. Tetapi Mukhopadhyay et al.,
(1982) dan Scherer (1974 cit. Nurfina, 1994) menduga bahwa hambatan ini terjadi karena kurkumin mempunyai struktur molekul dan reseptor mirip dengan protaglandin. Garg (1974) menyatakan bahwa pemberian kurkumin pada tikus menunjukkan efek antiferlitas (gagal bunting) sedang pada kelinci menunjukkan efek antiovulasi. Hasil penelitian ini menunjukkan bahwa kurkumin yang diberikan pada tikus bunting dapat menyebabkan fetus mati dan fetus cacat.

Berat badan dan panjang fetus antar kontrol dan perlakuan tidak menunjukkan perbedaan yang bermakna sehingga dapat diketahui bahwa kurkumin dalam penelitian ini tidak menimbulkan gangguan dan hambatan dalam pertumbuhan.

Fetus yang mengalami hemoragi terjadi pada kelompok P2, hal ini disebabkan karena dosis kurkumin yang diberikan melewati effective dose (ED) seperti yang disebutkan oleh Majeed et al., (1995). Mekanisme hemoragi dapat disebabkan oleh beberapa faktor antara lain ketidakseimbangan osmotik karena adanya gangguan tekanan dan viskositas cairan pada bagian fetus yang berbeda yaitu antara plasma darah dengan ruang ekstraseluler, atau antara cairan ekstraembrional dengan intraembrional. Pada keadaan normal embrio berkembang dalam cairan amnion yang isotonis dengan cairan tubuh (Setiawan, 2001). Diduga adanya kurkumin dalam jaringan fetus, dapat mengganggu keseimbangan osmotik sehingga terjadi pendarahan.

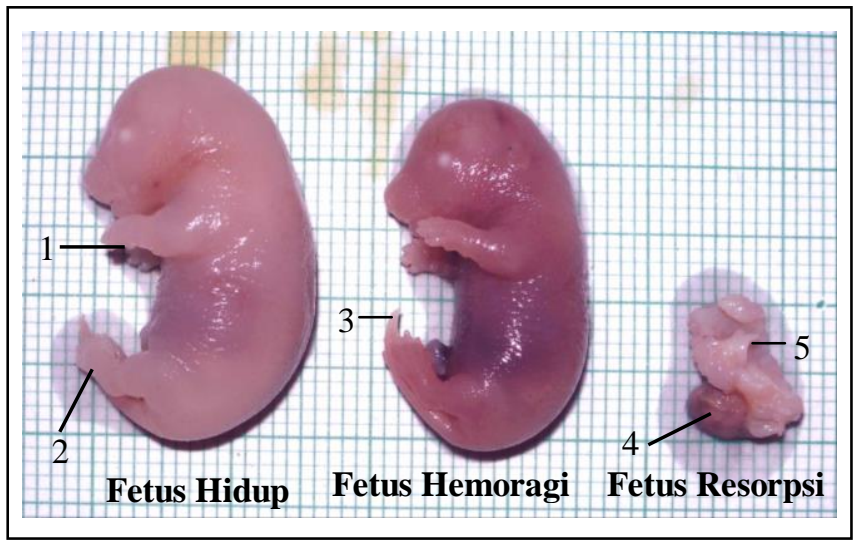

Gambar 1. Morfologi fetus dari induk yang diberi kurkumin pada hari ke-10 umur kebuntingan.

Keterangan: 1) tungkai depan, 2) tungkai belakang, 3) ekor, 4) plasenta 5) sisa jaringan fetus. 


\section{Fetus cacat dari induk yang diperlakukan dengan kurkumin}

Dalam penelitian ini fetus dari induk yang diberi kurkumin dosis $100 \mathrm{mg} / \mathrm{kg} \mathrm{bb}$, menunjukkan satu dari 35 (2,9\%) fetus dari kelompok ini, jari dari tungkai depan bagian kiri tidak terbentuk, sedang jari tungkai depan bagian kanan secara morfologi tampak normal. Morfologi fetus yang mengalami cacat ini dapat dilihat pada Gambar 2B, perkembangan anomali ini disebut "phocomelia" (tungkai depan pendek) unilateral.

Tulang rawan pembentuk ruas jari berkembang dari jaringan mesenkim (mesodermal) yang tersusun dari sel-sel bentuk bulat dengan juluran-juluran sitoplasma. Dalam perkembangannya sel-sel ini menarik juluranjuluran sitoplasma sehingga terjadilah kondensasi jaringan mesenkimal yang sangat seluler. Sel-sel ini merupakan prekursor sel-sel tulang rawan atau kondroblas, sel-sel ini penuh dengan ribosom dalam sitoplasmanya. Proliferasi, sintesis, dan pelepasan matriks menyebabkan sel-sel ini berjauhan, selanjutnya sel-sel multiplikasi sehingga terbentuk kelompok isogen yang dikelilingi oleh pemadatan matriks teritorial (kapsula) (Junqueira et al., 1998). Pada penelitian ini ujung-ujung jari anggota gerak depan tersusun oleh lapisan ektoderm dan mesenkim. Pada jari yang mengalami cacat phocomelia jaringan mesenkim pada daerah tertentu tidak mengalami pengelompokan atau kondensasi, hanya ada kondensasi mesenkim yang sangat kecil (Gambar 4C).

\section{Pengamatan mikroskopis efek kurkumin terhadap ujung jari tungkai depan fetus}

Pengamatan mikroskopis jari tungkai depan menunjukkan bahwa pada cacat fetus yang berupa phocomelia unilateral tidak terbentuk ruas jari yang seharusnya tersusun dari tulang rawan. Majeed et al., (1995) menyatakan bahwa pakan tikus dan kelinci bunting yang dicampur dengan kurkumin 0,6 dan $1,6 \mathrm{~g} / \mathrm{kg}$ bb. menunjukkan tidak toksik pada embrio, tetapi rangka mengalami abnormalitas. Pengamatan mikroskopis phocomelia menunjukkan bahwa sel-sel mesenkim tampak merupakan penyusun jaringan phocomelia.

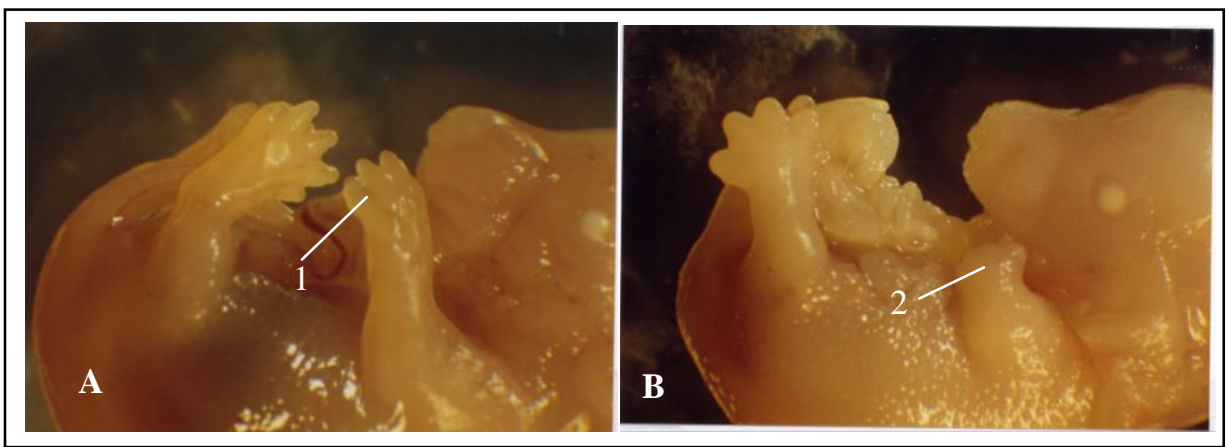

Gambar 2. Morfologi anggota gerak depan fetus dari induk yang diberi kurkumin pada hari ke-10 umur kebuntingan.

Keterangan: 1) Fetus dengan tungkai depan normal, 2) Fetus dengan tungkai depan cacat (phocomelia, unilateral).

Tabel 3. Efek kurkumin terhadap ujung jari tungkai depan fetus yang diamati secara mikroskopis.

\begin{tabular}{|c|c|c|c|c|c|c|c|c|}
\hline \multirow{4}{*}{ Interdigitasio } & \multicolumn{4}{|c|}{$\mathbf{K}$} & \multicolumn{4}{|c|}{$\mathbf{P}$} \\
\hline & \multicolumn{2}{|l|}{$=$} & \multicolumn{2}{|c|}{+} & \multicolumn{2}{|c|}{ P1 } & \multicolumn{2}{|c|}{$\mathbf{P 2}$} \\
\hline & kanan & kiri & kanan & kiri & kanan & kiri & kanan & kiri \\
\hline & antar ruas & 1 dan 2 & antar ruas & 1 dan 2 & pada ruas 1 & phocomelia & pada ruas 1 & pada ruas 1 \\
\hline Kondrogenesis & + & + & + & + & + & 0 & + & + \\
\hline Jaringan bakal kuku & 0 & 0 & 0 & 0 & + & 0 & + & + \\
\hline Pembuluh darah & + & + & + & + & ++ & 0 & ++ & ++ \\
\hline
\end{tabular}


Jaringan tersusun antara lain oleh sel-sel dan komponen extracelluler matrix (ECM) yang tersusun dari berbagai makromolekul hasil sekresi sel-sel jaringan. Pada jaringan embrional, peran ECM sangat penting untuk perkembangan yang berfungsi sebagai substrat dalam migrasi sel dan juga menginduksi sel-sel untuk berdiferensiasi. Tulang rawan pembentuk ruas jari berasal dari diferensiasi sel-sel mesenkim menjadi tulang rawan hialin, melewati proses proliferasi, migrasi, kondensasi, diferensiasi menjadi kondroblas dan akhirnya menjadi kondrosit (Junqueira et al., 1998). ECM yang berperan pada awal kondrogenesis adalah asam hialuronat, fibronektin, dan integrin. Dalam perkembangannya jaringan mesenkim yang akan membentuk tulang rawan tersusun oleh sel-sel mesenkim, yang tertanam dalam ECM yang aktif memperbanyak diri dan mensintesis fibronektin. Sel mesenkim selanjutnya berdiferensiasi menjadi kondroblas yang mampu mensintesis matriks tulang rawan, berproliferasi dan berdiferensiasi menjadi kondrosit. Komponen ECM yang disintesis oleh kondroblas dan kondrosit adalah kondroitin sulfat dan kolagen II (Haryono, 2005). Cacat fetus yang berupa phocomelia dapat dihubungkan dengan efek kurkumin yang menginduksi mesenkim menjadi kondroblas, tidak ada. Menurut Majeed et al., (1995) abnormalitas rangka pada fetus baru lahir dijumpai pada mencit bunting yang diperlakukan dengan kurkumin 1,6 g/kg pakan.

Pada kelompok kontrol interdigitasio terjadi antara ruas 1 dan 2 sedangkan pada kelompok perlakuan pada ruas pertama (Gambar 3). Hal ini diduga kurkumin menghambat apoptosis sel-sel penyusun jaringan interdigitasio. Pada kelompok perlakuan jaringan bakal kuku terbentuk, kemungkinan hal ini terjadi karena kurkumin merangsang sel-sel ektoderm untuk mensekresikan senyawa bakal kuku (Gambar 4B). Pada kelompok perlakuan pembuluh darah banyak terdapat dalam jaringan mesenkim. Apakah mungkin kurkumin dapat merangsang pembentukan Vaskular Endothelium Growth Factor (VEGF) sehingga terjadilah perkembangan sistem pembuluh darah (vaskulogenesis) yang berasal dari sel-sel mesenkhim (Gambar 4B). Mungkin hal ini juga yang menyebabkan terjadinya hemoragi. Menurut Dorai et al., (2001) kurkumin mempunyai efek antara lain sebagai antikanker. Kalau hal ini benar seharusnya kurkumin menghambat proliferasi, merangsang apoptosis, dan menghambat perkembangan mesenkhim membentuk pembuluh darah (angiogenesis).

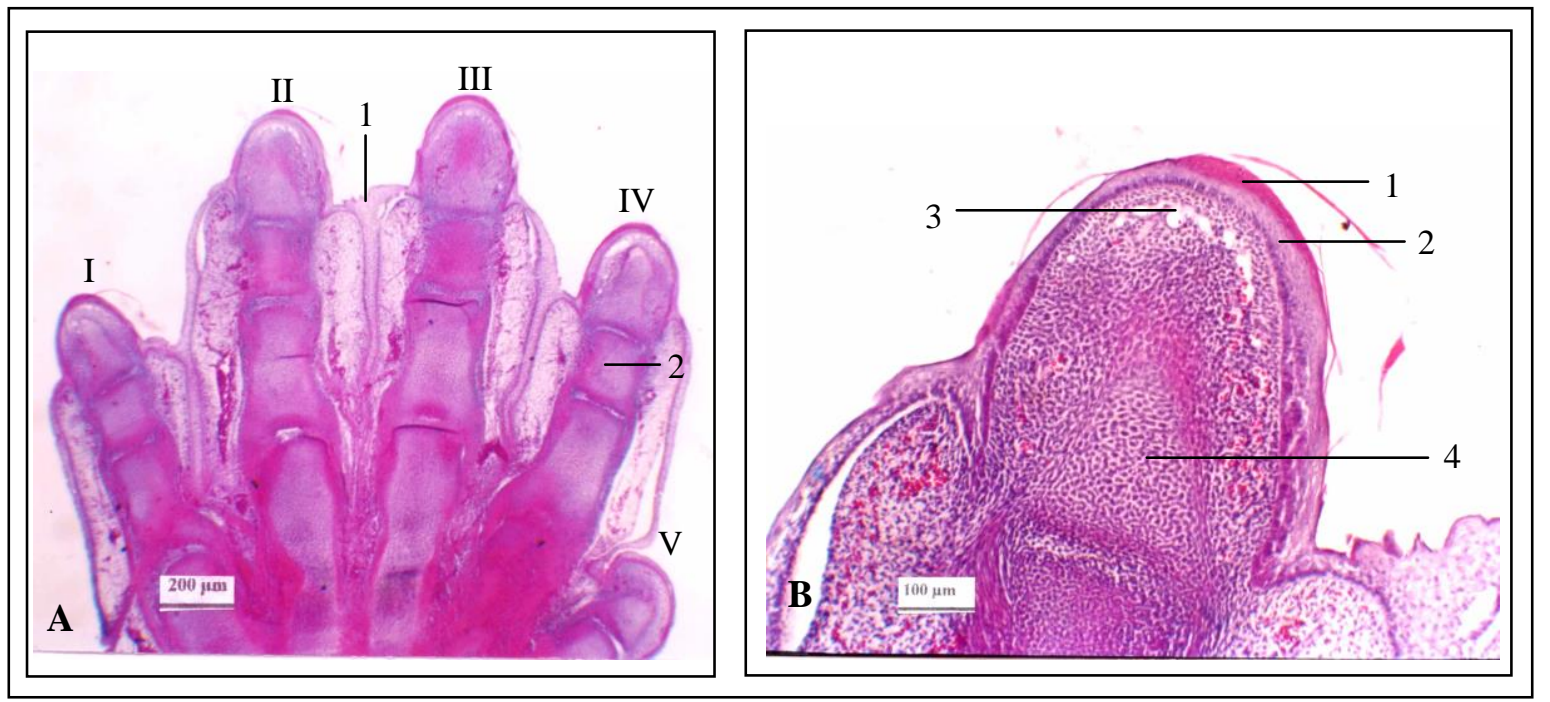

Gambar 3. Sayatan plantar jari tungkai depan kiri dari fetus kelompok kurkumin $100 \mathrm{mg} / \mathrm{kg}$ bb.

Keterangan: A. Perbesaran lemah Jari I, II, III, IV, dan V sudah terbentuk 1. indensitas interdigiti pada ruas ke-1 ; 2. ruas jari B. Perbesaran kuat 1. jaringan bakal kuku; 2. epidermis; 3. pembuluh darah; 4. bakal tulang rawan Lekukan antardigiti baru mencapai ruas jari ke-1. 


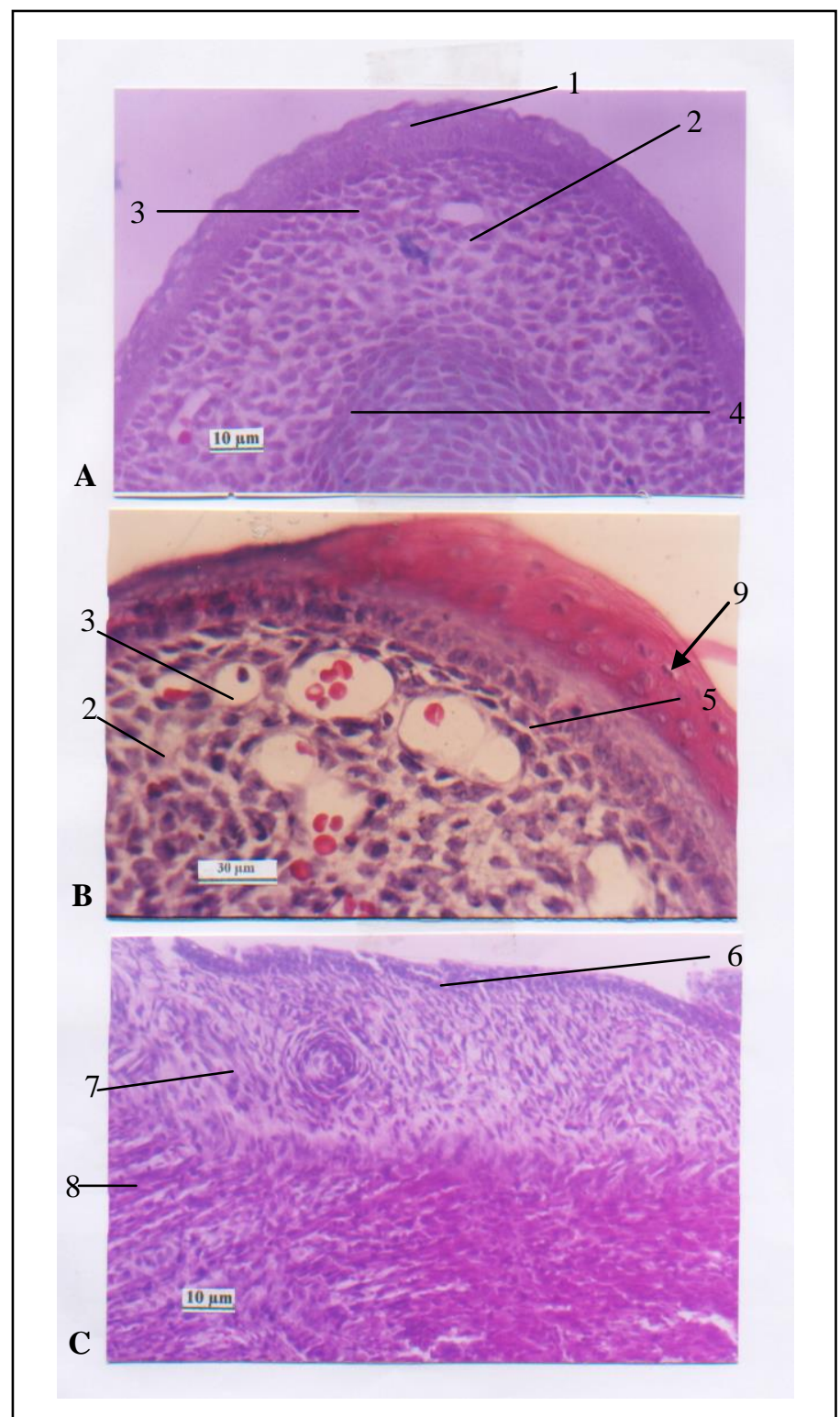

Gambar 4. Struktur mikroskopis ujung jari fetus dari induk yang diperlakukan dengan kurkumin.

Keterangan:

A. Ujung jari fetus dari kelompok kontrol dan plasebo

B. Ujung jari fetus dari induk yang diberi kurkumin $100 \mathrm{mg} / \mathrm{kg}$ bb

C. Ujung jari fetus abnormal (phocomelia) dari induk yang diberi kurkumin $100 \mathrm{mg} / \mathrm{kg}$ bb

1. Lapisan ektoderm; 2. Lapisan mesoderm; 3. Pembuluh darah; 4. Bakal tulang rawan (kondroblas tersusun rapat); 5. Epitelium pipih berlapis banyak akan membentuk bakal kuku (9); 6. Massa sel yang berasal dari lapisan ektoderm; 7. Kondensasi mesenkhimal; 8. Massa otot seran lintang. 


\section{Kesimpulan dan Saran}

\section{Kesimpulan}

Hasil penelitian ini menunjukkan bahwa kurkumin berpengaruh terhadap perkembangan jari tungkai depan fetus tikus dari induk yang diperlakukan kurkumin. Pengaruhnya tidak tergantung pada besarnya dosis (non dose dependent).

\section{Saran}

Mengingat bahwa aktivitas biologi kurkumin sangat luas, maka perlu dilakukan penelitian efek kurkumin dalam berbagai aspek.

\section{Ucapan Terima Kasih}

Tim Penyelenggara dan Pengembangan Penelitian Fakultas (TP3F) Fakultas Biologi Universitas Gadjah Mada yang telah memberikan kesempatan untuk melaksanakan penelitian ini. Ardaning Nuriliani, S.Si., M.Kes. dalam pengetikan naskah publikasi ini.

\section{Daftar Pustaka}

Chattopadhyay, I., Biswas, K., Bandyopadhyay, V. and Banerjee, R.K. 2004. Turmeric and Curcumin: Biological Actions and Medicinal Applications. Current Science. 87 (1): 10.

Chen, H.W. and Huang, H.C. 1998. Effect of Curcumin on Cell Cycle Progression and Apoptosis in Vascular Smooth Muscle Cells. $B r . \quad J$. Pharmacol. 124 (6): 1029-40.

Dorai, T., Cao, Y.C., Dorai, B., Buttyan, R. and Katz, A.E. 2001. Therapeutic Cancer III. Curcumin Inhibits Proliferation, Induces Apoptosis, and Inhibits Angiogenesis of LNCap Prostate Cancer Cell in vitro. Prostate 47 (4): 293-303.

Garg, S.K. 1974. Effect of Curcuma Longa (Rhizomes) on Fertility in Experimental Animal. Plant Medica 26: 225-227.

Haryono, A. 2005. Patogenesis Seluler Kelainan Jari Anggota Tubuh Depan Mencit Swiss Webster Yang Diinduksi Oleh Asam Maloksi asetat. Disertasi. Institut Teknologi Bandung, Bandung.
Ishida, T., Taketoh, J., Nakatsune, E., Kan-o, S., Naito, E., Takeda, S., Mutoh, J., Ishii, Y. and Yamada, H. 2004. Curcumin Anticipates the Suppressed Body Weight Gain with 2,3,7,8Tetrachlorodibenzo-p-Dioxin in Mice. J. of Health Sc. 50 (5): 474-482.

Jiang, M.C., Yang-Yen, H.F., Yen, J.J. and Lin, J.K. 1996. Curcumin Induces Apoptosis in Immortalized nim3T3 and Malignant Cancer Cell Line. Nutr. Cancer 26 (1): 111- 20.

Joe, B., Vijaykumar, M. and Lokesh. 2004. Biological Properties of Curcumin-Cellular and Molecular Mechanisms of Action. Food Science and Nutrition 44: 97-111.

Junqueira, L.C., Carneiro, J. and Kelly, R.O. 1998. Basic Histology. Appleton \& Lange, Stanford, Connecticut. p. 127-132.

Majeed, M., Badmaev, V., Shivakumar, U. and Rajendran, R. 1995. Curcuminoid. Antioxidant phytonutrients. Nutri Science Publisher, Inc., New Yersey p.45.

Mukhopadhyay, A., Basu, N., Gathak, N. and Gujral, P.K. 1982. Antiinflammatory and Irritant Activities of Curcumin Analogues in Rat. Agent and Action 2: 153-160.

Nurfina, A. 1994. Synthesis of Some Symetrical Curcumin Derivates and The Study of Their Antiiflammatory Activities as well as Structure-activity Relationships. Disertation, Gadjah Mada University, Yogyakarta.

Pan, M.H., Huang, T.M. and Lin, J.K. 1999. Biotransformation of Curcumin Through Reduction and Glucuromidation in Mice. Drug Metab. Dispos. 27 (4): 486 - 94.

Setiawan, A. 2001. Pengaruh Morfin terhadap Pertumbuhan, Perkembangan Embrio dan Skeleton Fetus Mencit (Mus musculus L.). PS. Biologi. Program Pascasarjana Universitas Gadjah Mada Yogyakarta.

Sri, H. 2006. Posisi Reseptor Folikel dan Kemampuan Ovulasi Rattus norvegicus strain Wistar setelah Pemberian Pentagamavunon-0. PS. IKD dan Biomedis. Sekolah Pasca Sarjana Universitas Gadjah Mada Yogyakarta. 